Gut, 1977, 18, 623-625

\title{
Exocrine pancreatic response to the venom of the scorpion, Tityus trinitatis
}

\author{
C. BARTHOLOMEW, J. J. MURPHY, K. F. MCGEENEY, AND O. FITZGERALD \\ From the Department of Medicine, University of the West Indies, General Hospital, Port-of-Spain, Trinidad, \\ and the Departments of Medicine and Therapeutics and of Surgery, University College, Dublin, Ireland
}

SUMMARY This paper records for the first time the exocrine pancreatic response to scorpion venom, in this case that of Tityus trinitatis, a scorpion endemic in Trinidad. The crude venom injected intravenously into fasting anaesthetised dogs induced a secretion of the exocrine pancreas. The secretion evoked was rich in enzymes.

Acute pancreatitis has been described after the sting of the scorpion of Trinidad, Tityus trinitatis (Waterman, 1938; Poon-King, 1963; Bartholomew, 1970). Bartholomew (1970) in his series reported 30 cases of scorpion stings, 24 of whom had clinical features of acute pancreatitis with raised serum amylase. Waterman (1938) had reported finding at laparotomy two cases of acute oedematous pancreatitis, two of haemorrhagic pancreatitis, and 12 with pseudocysts of the pancreas after stings of Tityus trinitatis. Many workers have reported stimulation of secretion from salivary and lacrimal glands (Bücherl and Buckley, 1971) and of adrenal glands (Henriques et al., 1968) after envenomation; however, there have been no reports of pancreatic secretion after envenomation by this or any other venom. This work was undertaken to examine the action of the venom of Tityus 'trinitatis on the exocrine secretion of the canine pancreas.

\section{Methods}

In fasting mongrel dogs, anaesthesia was induced with Epontal (Bayer), a non-barbiturate agent of very short duration of action and continued with chloralose intravenously, an anaesthetic agent known to have only minimal pancreatic action. Endotracheal intubation was maintained throughout the experiments and assisted respiration when necessary. Laparotomy was performed through a small upper mid-line incision. With careful technique to minimise handling of the pancreas, a cannula was inserted for a short distance into the pancreatic duct near its termination without opening the duodenum. The

Received for publication 10 December 1976 cannula was then secured and the laparotomy incision closed. A venous catheter was introduced into the femoral vein and advanced into the inferior vena cava.

Crude venom of the scorpion Tityus trinitatis obtained by electrical milking was stored as a dry powder at $-20^{\circ} \mathrm{C}$. The dried venom was dissolved in normal saline immediately before use and was administered slowly through the venous catheter.

Pancreatic juice was collected under oil in weighed tubes. Amylase was measured by the Phadebas method (Ceska et al., 1969), lipase activity was measured on an emulsified olive oil substrate and trypsin activity resulting from the canine enterokinase activation of the pancreatic juice was measured by the Bapna method of Erlanger et al. (1961). All measurements were made on 10 or 15 minute collections of pancreatic juice.

\section{Results}

A range of doses of venom was first given to three $10-11 \mathrm{~kg}$ dogs in order to establish a dose which produced an exocrine pancreatic response. Doses of $0.1 \mathrm{mg}, 0.2 \mathrm{mg}, 0.3 \mathrm{mg}, 0.4 \mathrm{mg}$, and $1.0 \mathrm{mg}$ produced no pancreatic response. In the $10 \mathrm{~kg}$ dog shown in Fig. 1, after an injection of $2.0 \mathrm{mg}$ venom which evoked no pancreatic response, an injection of $4.0 \mathrm{mg}(0.4 \mathrm{mg} / \mathrm{kg})$ of venom evoked the following response: volume output $0.58 \mathrm{ml}$, amylase $1.1 \mathrm{KU}$, lipase $382 \mathrm{KU}$, and trypsin $8.9 \mathrm{mg}$.

In another animal with a basal unstimulated pancreatic output $0.42 \mathrm{ml}$, amylase $0.6 \mathrm{KU}$, lipase 47.7 $\mathrm{KU}$, and trypsin $4.1 \mathrm{mg}$ over a 10 -minute period, the intravenous injection of $10 \mathrm{mg}$ venom $(1 \mathrm{mg} / \mathrm{kg})$ increased the output in the following collection 

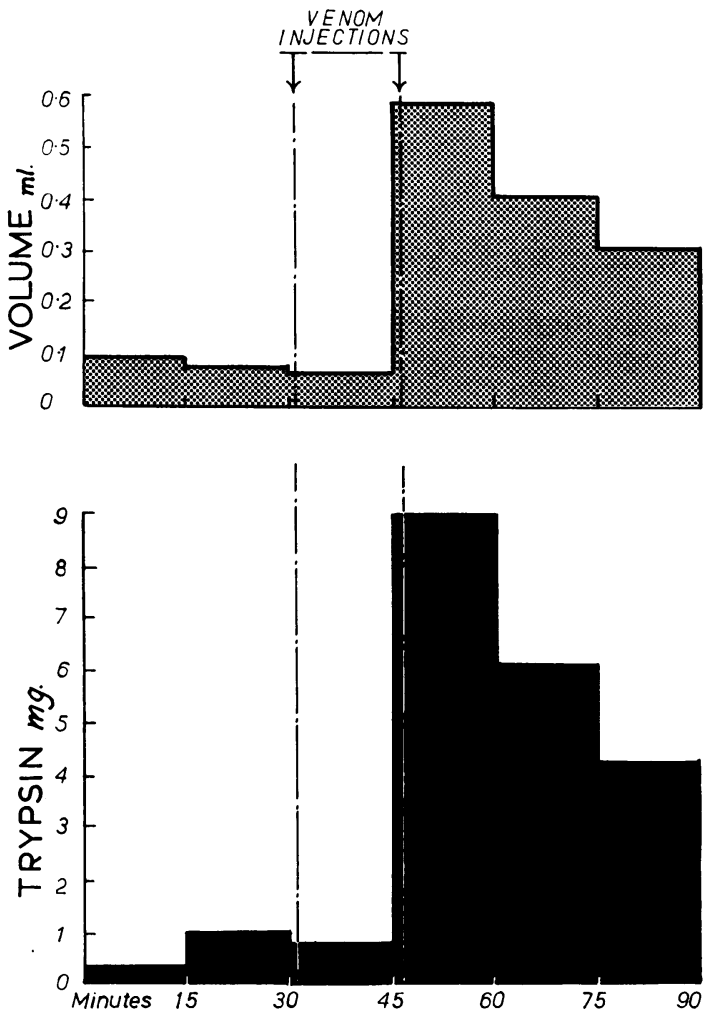

Fig. 1 Pancreatic response to venom. Dog given $2.0 \mathrm{mg}$ vonom $(0.2 \mathrm{mg} / \mathrm{kg})$ at time 31 minutes followed by $4.0 \mathrm{mg}$ venom $(0.4 \mathrm{mg} / \mathrm{kg})$ at time 46 minutes.

period to $0.92 \mathrm{ml}$ volume, amylase $10.7 \mathrm{KU}$, lipase $198 \mathrm{KU}$, and trypsin $16.7 \mathrm{mg}$. In the following collection period the output fell to volume $0.09 \mathrm{ml}$, amylase $0.6 \mathrm{KU}$, lipase $43.7 \mathrm{KU}$, and trypsin $2.6 \mathrm{mg}$.

The pancreatic response in another dog to serial injections of $11 \mathrm{mg}$ venom $(1.0 \mathrm{mg} / \mathrm{kg}$ body weight $)$ is shown in Figs. 2 and 3. The response in this animal is interesting in that it showed an increasing rate of enzyme secretion with repetition of the stimulus.

In the animal shown in Fig. 4, the pancreas was stimulated throughout the experiment by a continuous intravenous infusion secretin (Boots) $16 \mathrm{U} / \mathrm{h}$. After an initial stabilisation period venom $(1 \mathrm{mg} / \mathrm{kg}$ ) was administered. A very slight increase in volume resulted but the enzyme output increased from $0.3 \mathrm{KU}$ to $2.8 \mathrm{KU}$ amylase. The concentration of the secreted enzyme increased from $0 \cdot 15 \mathrm{KU}$ to $1 \cdot 1 \mathrm{KU} / \mathrm{ml}$.

\section{Discussion}

The secretory effects of scorpion venoms on various

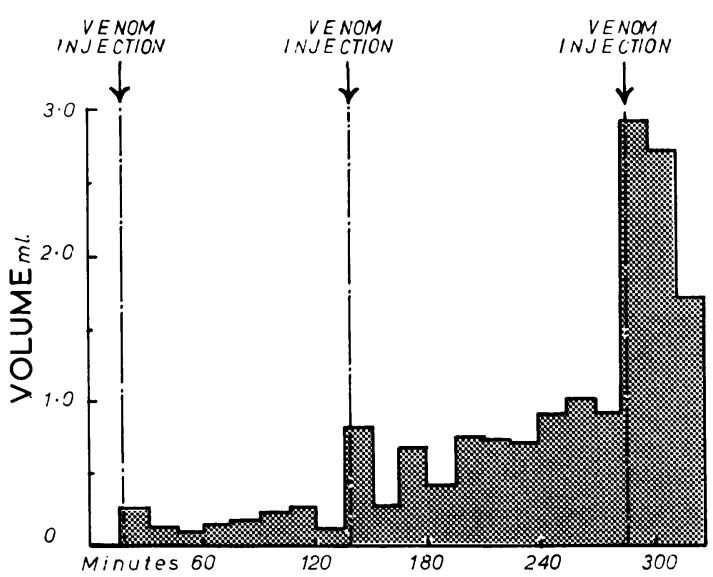

Fig. 2 Volume response to multiple injections of venom. Dog given $11 \mathrm{mg}$ venom $(1 \mathrm{mg} / \mathrm{kg})$, at times indicated.

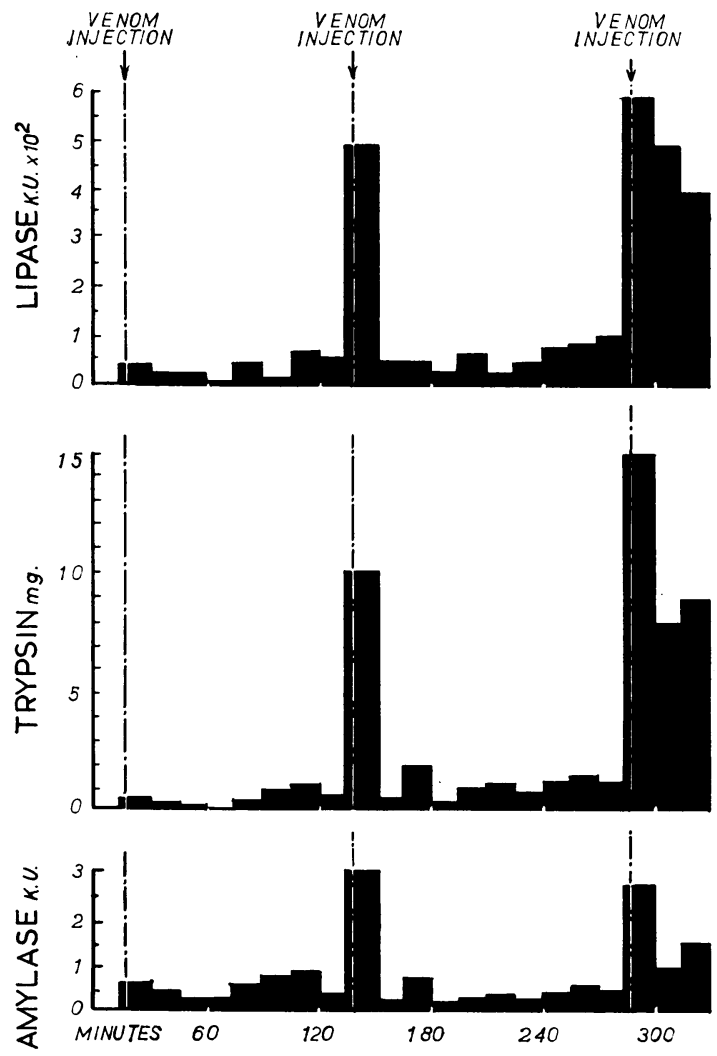

Fig. 3 Enzyme response to multiple injections of venom. Dog given venom, $11 \mathrm{mg}(1 \mathrm{mg} / \mathrm{kg})$ at times indicated 

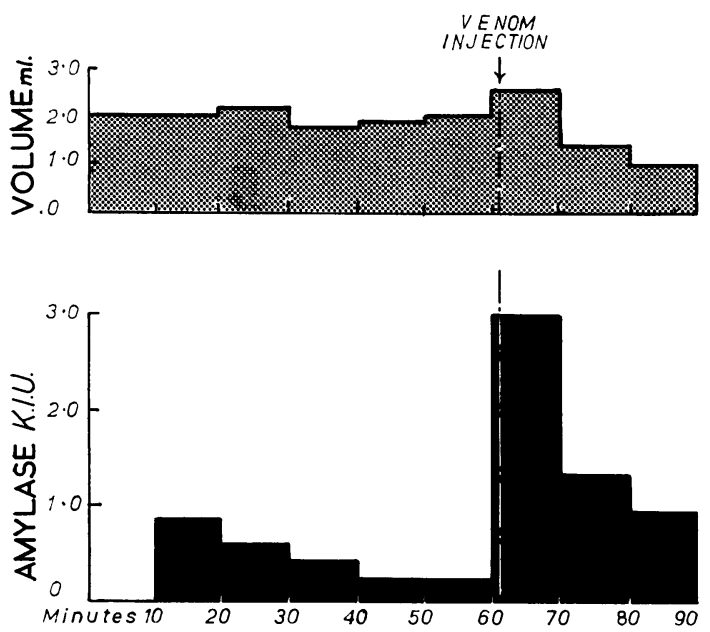

Fig. 4 Pancreatic response to venom during continuous infusion of secretin, $16 \mathrm{U} / \mathrm{h}$. Venom, $10 \mathrm{mg}(1 \mathrm{mg} / \mathrm{kg})$, given at time 61 minutes.

glands have been reported. It is well known that scorpion venom causes increased salivary and lacrimal secretions (Bücherl and Buckley, 1971) and adrenal secretion (Henriques et al., 1968) but no reports have ever been published on the effect of scorpion venom on pancreatic secretion.

The observation that acute pancreatitis frequently occurs in Trinidad after the sting of the scorpion Tityus trinitatis prompted the investigation of the effect of this venom on the exocrine pancreas. The results of this study on fasting anaesthetised dogs with cannulated ducts show that the crude venom is a pancreatic secretagogue evoking a juice that is rich in enzyme content. Against a background infusion of secretin $16 \mathrm{U} / \mathrm{h}$ the venom caused a very slight increase in flow but a significant increase of enzyme output and concentration.

Effects on other organs were observed during various stages of envenomation in this studynamely, salivation, lacrimation, and cardiac arrythmias. Scorpion venoms are known to contain neurotoxins which result in the release of acetylcholine at the neuromuscular junction from post- ganglionic parasympathetic neurons (Benoit and Mambrini, 1967; Diniz and Torres, 1968; Henriques et al., 1968; Katz and Edwards, 1972; Gomez et al., 1973) and the clinical syndrome resulting from scorpion poisoning and its rapidity of action reflect this.

The venom of Tityus trinitatis is shown in this study to evoke an exocrine pancreatic response slight in volume but rich in enzymes similar to that known to be evoked by acetylcholine. Accordingly, we suggest that the secretory action of the venom of Tityus trinitatis may also be caused by the release of acetylcholine from nerve endings to the pancreas.

We wish to thank Mr R. Martinez for milking the scorpions and Mrs M. Sharp for technical assistance. This work was supported by a grant from the Wellcome Trust, London.

\section{References}

Bartholomew, C. (1970). Acute scorpion pancreatitis in Trinidad. British Medical Journal, 1, 666-668.

Benoit, P. R. and Mambrini, J. (1967). Action du venim de scorpion sur la jonction neuromusculaire de la grenouille. Journal of Physiology (Paris), 59, Suppl., 348.

Bücherl, W. and Buckley, E. (1971). Venomous Animals and their Venoms. vol. 3. Academic Press: London.

Ceska, M., Hultman, E., and Ingelman, B. G.-A. (1969). A new method for determination of alpha-amylase. Experientia, 25, 555-556.

Diniz, C. R., and Torres, J. M. (1968). Release of an acetylcholine-like substance from guinea pig ileum by scorpion venom. Toxicon, 5, 277-281.

Erlanger, B. F., Kokowsky, N., and Cohen, W. (1961). The preparation and properties of two new chromogenic substrates of trypsin. Archives of Biochemistry and Biophysics, 95, 271-278.

Gomez, M. V., Dai, M. E. M., and Diniz, C. R. (1973). Effect of scorpion venom, tityustoxin, on the release of acetylcholine from incubated slices of rat brain. Journal of Neurochemistry, 20, 1051-1061.

Henriques, M. C., Gazzinelli, G., Diniz, C. R. and Gomez, M. V. (1968). Effect of the venom of the scorpion Tityus serrulatus on adrenal gland catecholamines. Toxicon, 5 , 175-179.

Katz, N. L., and Edwards, C. (1972). The effect of scorpion venom on the neuromuscular junction of the frog. Toxicon, 10, 133-137.

Poon-King, T. (1963). Myocarditis from scorpion stings. British Medical Journal, 1, 374-377.

Waterman, J. A. (1938). Some notes on scorpion poisoning in Trinidad. Transactions of the Royal Society for Tropical Medicine and Hygiene, 31, 607-624. 